\title{
NATO AND EU ROLE IN DEALING WITH COVID-19
}

\author{
Andrej Iliev ${ }^{44}$, Nenad Taneski ${ }^{45}$ \\ Military academy "Gen. Mihailo Apostolski", Skopje
}

\begin{abstract}
Starting withhistorical premise that every century for the past few centuries, we have at least one pandemic such as: flu, fever, plague and other types of viruses.So according to this, if we make an historical review and analysis we will see that some of them have caused greater human losses thanthe First and Second world war.The introductory part of our paper will give a brief historical overview of the global pandemic that have occurredthe world in the last few centuries and along with this, which lessons have the worldlearned from them. In our paper, we will focus on the analysisof NATO and the European Union role in dealing with COVID-19.

Here we will analyze: NATO and EU readiness to respond to military and non-military crises, their capacities and capabilities, taking effectivemeasures to respond on COVID-19 crisis, logisticalcapabilities and coordination, critical points of NATO and EU missionin order effectively to respond on COVID-19 crisis, operational and action plan and their preparation for the next waves of COVID-19,NATO and EU level of political and military diplomacy with China and Russia for support and overcoming COVID-19 more effectively.

Further, NATO and EU preparations for establishment of a crisis response force for COVID-19, level of complementarity and cooperation between NATO and EU in dealing with COVID-19, NATO and EU medium- and long-term plans for effective response to COVID-19 and their other measures and activities.

Having in mind, the above mentions measures and activities of NATO andEU for dealing with COVID-19, the main goal of this paper will be to make an historical overview and analysis ofeffects from already taken measures and activities from NATO andEU, as well as further directions for improvementofoverall activity in dealing with COVID-19.
\end{abstract}

Keywords: historical review, NATO, EU, role, dealing with COVID-19

\section{Introduction}

More than 20 (twenty) cases of pandemics caused by influenza, fever, viral infections and others are known in the world from antiquity until today. For the past few centuries, every century has been marked by at least one global pandemic.

During the years 1720-23, historical sources acquaint us with the Great Plague in Marseilles, which according to historical documentation began when the ship "Grand-SaintAntoine stopped at the port of Marseilles in France. This ship was carrying goods from the eastern Mediterranean. Although all preventive medical measures were taken so that the

${ }^{44}$ Contact address: andrej.iliev@ugd.edu.mk

${ }^{45}$ Contact address: nenad.taneski@ugd.edu.mk 
ship was quarantined, the plague entered the city of Marseilles through rodents which in turn were infected with the plague. The plague spread rapidly among the population and over the next three years more than 100,000 people died in Marseilles and surrounding areas.

During 1817 the first global cholera pandemic appeared. It first spreads from Calcutta to the Delta in recent years. The cholera pandemic has resulted in millions of lives lost. Decades later in 1854 at Broad Street in the Soho district of London, according to national medical institutions and the famous English physicist John Snow, said that cholera was most commonly transmitted through contaminated water. It was later determined that certain water pumps for public use had been contaminated with cholera. With the detection of these water pumps for public use and their disinfection and remediation, the intensity of cholera spreading has been significantly reduced. The next century during 1918-1919, just before the end of First World War (1914-18), according to modern historians, a pandemic of the so-called "Great Fever" appeared (Taubenberger, Morens, 2000 :16-17).

The cause of "Great Fever" Pandemic was the H1N1 virus, which according to some scientific studies were the main carriers of a certain species of birds. On the other hand, there is no general consensus on the exact origin of the virus. The virus was first identified in military personnel in the United States in early 1918. Worldwide, an estimated 500 million people worldwide have been infected with the virus.

Out of total 500 million infected people worldwide, about $10 \%$ or 50 million people have lost their lives as a result of the virus. In the United States alone, nearly 700,000 people have died from the virus (Tardy, 2017: 15-18).

The "Great Fever" pandemic, known worldwide as the "Spanish flu", didn't originate in Spain, but only Spain in this period of time continuously reported daily on the conditions and preventive measures related to the global pandemic of this type of fever. Spanish fever is a global virus that infected the world shortly after the end of World War I (1914-1918) and is one of the deadliest viruses in human history, claiming as many lives as World War II (1941-1945). The biggest challenge in estimating the effects of the 1918 pandemic are poor data quality as well as the existence of concurrent events (Beach, Karen, Saavedra, 2020:5-7).

In the current century or more precisely since December 2019, the world has been occupied by the coronavirus COVID-19, which causes several types of acute respiratory syndrome, the so-called SARS COV-2. The virus was first identified in the Chinese city of Wuhan in early December 2019. Shortly afterwards, the closure of the city of Wuhan and the quarantine of Hubei Province began.

The World Health Organization declared a global coronavirus pandemic COVID-19 on 11-th of March 2020. Since the beginning of 2021, several variants of this virus have been identified such as: alpha, beta, delta. From this types of virus variants, beta variant of the virus proved to be the most virulent. From December 2019 to September 7, 2021, the coronavirus COVID-19 infected about 222 million people, of which unfortunately 4.6 million people died and about 199 million people were cured (Worldmeter,2021). Having in mind the unpredictable timeline of the virus and also the number of infected and dead persons, COVID-19 is one of the most dangerous viruses in world history. The symptoms of the virus range from inconspicuous to life-threatening. Most of the deaths from this virus are older groups of people and people which have had various chronic diseases. The virus is most commonly transmitted when people breathe contaminated air from droplets and small air particles. Inhalation of contaminated virus particles into the air is usually transmitted from person to person when people stay 
in the same room for a long time or when they stay for a short time closer to each other from 2 meters. The presence and asymptomatic persons who do not develop or develop mild symptoms of the virus could easily transmit and spread the virus to other persons. The World Health Organization mentions as preventive measures for protection against this type of virus are: social distance of 2 meters, wearing a protective mask, regular ventilation of the public and ordinary rooms, increasing the level of hygiene and regular use of disinfectants. From the second half of 2020, several types of vaccines for protection against the virus are in use.

\section{NATO during COVID-19}

If we make an historical retrospective of engaged health, military and other forces as well as their mutual cooperation in order to deal more effectively with the Spanish flu, we can easily conclude that all this happened more than a century ago and for today represent a historic lesson for the future role of NATO and EU in dealing with non-military threats (Wever, Bergen, 2014, 538-540). The first serious attempts to form the so-called "Protection Forces" from the global pandemic of the Spanish flu were formation of a joint military-medical force, which immediately after the end of the First World War from 1918 onwards was very complex. All of this was because political and military leaders were morally, psychologically and mentally affected by the aftermath of World War I. In this situation, the capacity of the medical staff was focused on the prevention and treatment of the wounded and sick as a result of the war and they were not sufficiently consolidated to respond effectively to the challenges of the global flu pandemic from Spanish flu(Snyder, 2009).

In June 1998, NATO established the Euro-Atlantic Disaster Response Coordination Center (EADRCC), as a "clearing-house mechanism" for collective coordination and as a institution ready any time to provide international support to NATO members and Partnership for Peace countries (PfP) (NATO, 2021).

\section{Q. NATO NATO EADRCC Clearing House Mechanism \\ OTAN requesting international assistance in 3 simple steps}
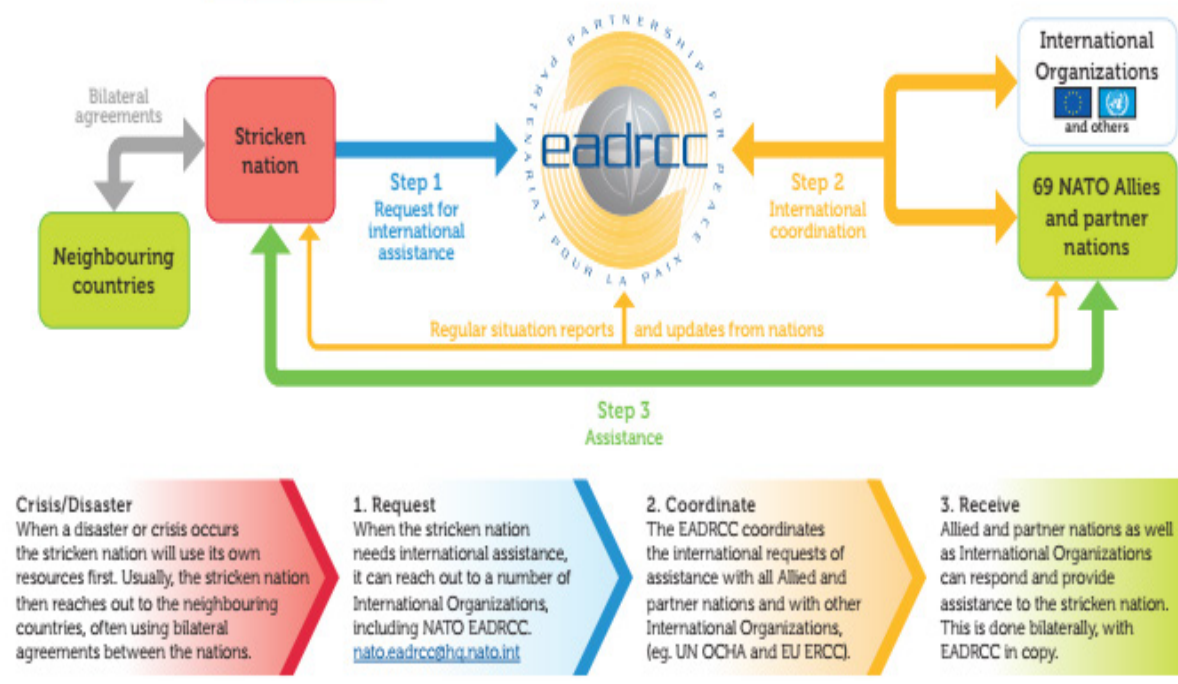

1. Request

When the stricken nation.

needs international assistance,

it can reach out to a number of International Organizations, including NATO EADRCC. nato eadrceghanato.int
2. Coordinate

The EADRCC coordinates

the international requests of

assistance with all Alived and

partner nations and with other

International Organizations,

(eg. UN OCHA and EU ERCC).
3. Receive

Allied and partner nations as well as International Organizations can respond and provide assistance to the stricken nation. This is done bilaterally, with EADRCC in copy.

\section{EADRCC Clearing house mechanism}


The EADRCC Clearing house mechanism(NATO. (2020), as an institution or body of the NATO Alliance covers geographical area of more than 50 countries, including the Partnership for Peace (PfP) countries. One of the core tasks of EADRCC is to provide the necessary support and assistance to this countries exposed to radiological, chemical and biological attacks and incidents. Thus, this functional NATO institution, in addition to NATO member states, also supports the partner countries of the Istanbul Cooperation Initiative, as well as the countries of Mediterranean Dialogue on a global level (Latici, 2020:1-2).

The EADRCCworks closely with United Nations Office forCoordination of Humanitarian Affairs (UN Global initiative against transnational organized crime, 2020: 3-5), which is responsible for coordinator for any international disaster and relief operation (Mesterhazy, 2020: 3-4).In fact, the geographical area covered by the EADRCC covers nearly 70 countries worldwide. EADRCC operates $24 / 7$ on a coordinated response, support and assistance basis. Coordinating assistance and support includes medical and financial support. During June 2020, NATO Defense Ministers decided to adopt a new Operational Plan to ensure the Alliance's readiness and ability to assist when needed by its Member States and its partners (NATO, 2021:1-2).NATO has established NATO Pandemic Response Trust Fund for effectively deal with COVID-19 pandemic in order for this body to be able to deliver medical equipment and services quickly and efficiently. NATO supports creative scientific research and cooperation with other international organizations and institutions such as the UN, EU and others in order to prevent the global pandemic with COVID-19.

As an example, we will highlight the role of NATO Science and Technology Organization, whose network includes over 6000 scientists. During April 2020, this NAT0 body had identified several solutions to overcome the current challenges in dealing with COVID-19. Over 40 international projects are currently underway and most of them are about finding methods and ways to deal with the current pandemic.

Furthermore, NATO Science and Technology Organization, together with the NATO Center for Maritime Research is conducting US supported experimental research for modelling capacities and capabilities for effectively prevent the spread of COVID-19.

Through the NATO project program, NATO Science for Peace and Security (NATOSPS), Italy and Sweden are working on a serious international project for rapid and efficient diagnosis of COVID-19. In the most critical moments of spreading COVID-19, NATO through its bodies, gave support to several NATO partner countries and members such as: Montenegro, Estonia, Netherlands, Poland, Turkey, Czech Republic, Hungary, Norway, Slovenia and our state. NATO, as a military-political alliance, doesn't have sufficient experience in dealing with global health crises, such as the current COVID-19. Thus, the lessons learned so far in terms of providing an appropriate effective and coordinated response to COVID-19 prevention came from the following future recommendations:

- Resilience: NATO must remain vigilant against malign exploitation of crises;

- NATO should have a protocol to follow in case of crises like pandemics to ensure continuity;

- NATO should be more efective in counter disinformation efforts and protect its member states against actors exploiting crises to promote their geostrategic interests (Giovanna, $2020: 8-9$ );

- NATO and crisis readiness: NATO must further enhance its crisis management toolkit;

- Strengthen the international network of the Euro-Atlantic Disaster Relief Coordination 


\section{Center (EADRCC);}

- Contently increasing NATO knowledge for: prediction capabilities and awareness of actual and further regional and global crisis;

- Constantly improving the cooperation of NATO with EU in field of building better capacities and capabilities for dealing with actual and future pandemics such as COVID-19 ( Iftimie, 2020: 53-55).

\section{EU during COVID-19}

During the COVID-19 health crisis, EU provided ongoing financial and material support to EU Member States and Partners through its SURE instrument and the Corona Virus Response Investment Initiative (CRII). The above-mentioned EU bodies have a strategic goal, to prevent as much as possible and more effectively preventing the all consequences that could occur from the COVID-19 pandemic. So far over EUR 90 billion has been used through the SURE instrument (Becker op.cit al, 2021:12-14).

With this instrument the EU provided support to 19 member states or for 30 million people who needed medical assistance and also this instrument provided financial support to around 2.5 million companies (European commission, 2021:14-17).

EU engagements under the Common Security and Defense Policy (CSDP) focusing on EU's operational level during the execution phase (Zartsdahl, 2018: 197-198).Having in mind the current challenges posed by the current global health crisis caused by COVID-19, EU should focus on urgent and action in relation to the countries of South East Europe:

- Delivery of necessary medical materials and equipment should go according to the number of population or the real needs for medical equipment equally and proportionally for all countries from the region of Southeast Europe;

- The EU should accelerate the process of integration with countries of Southeast Europe aspiring to EU membership, so in this direction EU should revise the existing methodology in order to make it easier for understanding for the countries aspiring to EU membership. The process of negotiations for membership in the European Union of the Republic of Albania and the Republic of North Macedonia should be intensified as soon as possible;

- Formal approval forstarting the negotiations of the above countries aspiring for EU membership during the current health crisis caused by COVID-19, will give a clear signal to the entire European public that the next steps towards better organization, coordination and cooperation of EU member states in the direction of effectively overcoming the pandemic with COVID-19 goes in the right direction;

- EU should involve all countries in the region of Southeast Europe in the process of post-pandemic recovery plans by proposing additional funds for more easily overcoming the economic and social crisis caused by COVID-19 pandemic.

- European Union Solidarity Fund should be equally and proportionately available for all countries inregion of Southeast Europe and should be used according to current needs and consequences caused by COVID-19 pandemic (BiEPAG, 2020:14-15);

- The future current operational plans of EU should improve its efficiency and coordination for response to health crisis caused by COVID-19 and also for including health authorities from the countries of Southeast Europe Europe in EU Policy Advisory Group; 
- EU in coordination with NATO should make a transparent agreement to allow Chinese companies to be able to supply the countries of region of Southeast Europe with necessary medical equipment for more effectively dealling with consequences caused by COVID-19 pandemic.

\section{NATO and EU cooperation during COVID-19}

This year are marked five years since the signing of Joint Declaration from 8-th July 2016 by the President of European Council, President of European Commission and the Secretary General of NATO. Having in mind the challenges from COVID-19 pandemic, political dialogue between NATO and EU has intensified at all levels. The strengthening of mutual cooperation was intensified through the strengthening of mutual understanding, transparency, self-confidence and strong mutual support (European Parliament, 2021: 32-33).

During December 2020, the first more serious meeting of the NATO Secretary General with the President of the European Commission was realized, which concluded that more efficient joint cooperation is needed for timely response and prevention from the challenges of COVID-19 (Wemer, 2020, NAT0 Allies have stepped up to help each other during Coronavirus, viewed 10.09.2021,https://atlanticcouncil.org/blogs/new-atlanticist/nato-allies-have-steppedup-to-help-each-other-during-coronavirus-emergency).

In this regard, the participation of EU High Representative in the meetings of NATO Foreign and Defense Ministers stressed the strategic importance of the partnership between NATO and the EU in all areas, especially in areas for overcoming current pandemic with COVID-19. The good mutual cooperation also gave concrete results. Through the implementation of regular meetings of North Atlantic Council (NAC) and the EU Political and Security Committee (PSC), regular meetings and concrete future steps of the EU and NATO defense planning process, especially in testing the capabilities and capabilities of the multi-role tanker-Transport (MRTT) aircraft were agreed.

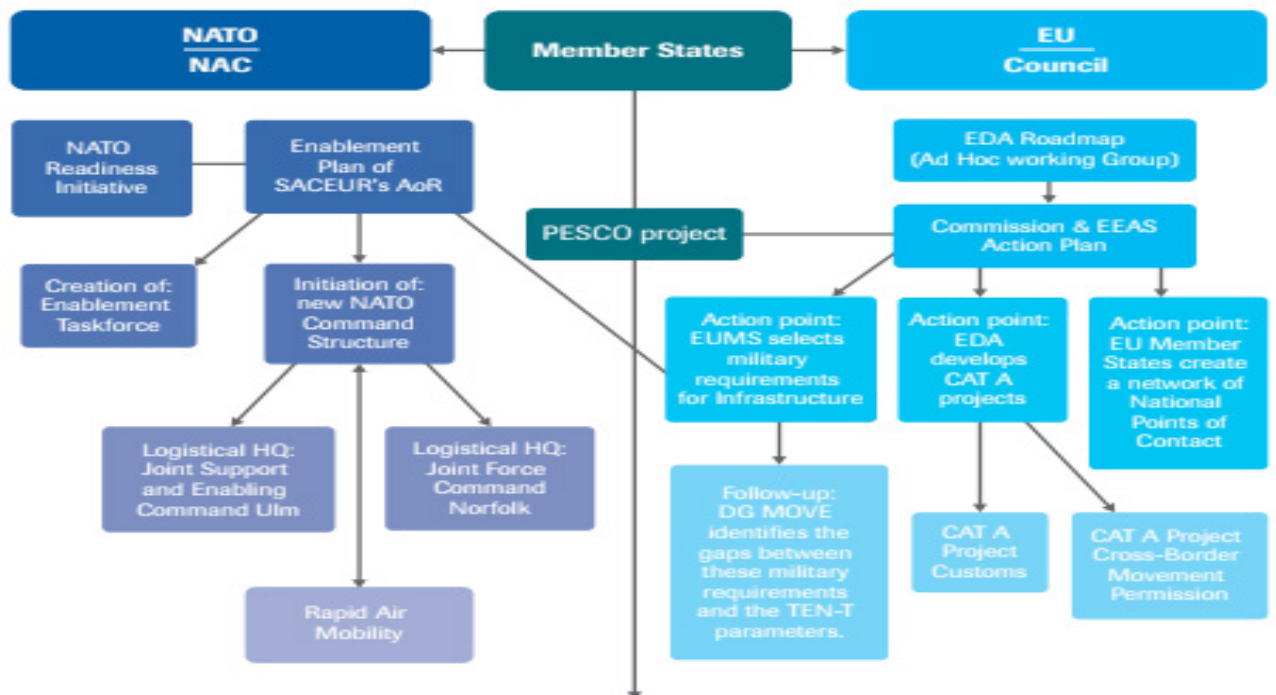

NATO and EU overview of stakeholder involvement cooperation

(Drent, Kruijver, Zandee, 2019: 3-4) 
The European Multilateral Security and Defense Institutions together with the NATO members created an active platform for sharing information on COVID-19. This includes the formation of individual rapid response forces for global pandemics such as COVID-19 (NATO, 2020).

The Republic of Spain was one of the most affected countries by COVID-19, so first Madrid received direct support and assistance from the EADRCC or more precisely from: Czech Republic, Turkey, Germany, Luxembourg and Lithuani (Gobierno De España - Minister for Defence underlines (2020) "Need for coordination between NATO and EU" to tackle COVID-19. NATO transported the necessary medicines for prevention from COVID-19 through using two basic programs: Strategic Airlift Capability and Strategic Airlift International Solution (SALIS) (Lye, Harry. (2020). The further future cooperation of NATO and EU in segment of coordinated management and prevention of future crises similar to the current health crisis, should be further upgraded with strengthening the existing logistics capacities, building civil protection mechanisms, unified approach for responding in time of health crises. And finally, establishing a joint coordination center for dealing with health crises.

In this context we will mention the statement of Malcom Chalmers, deputy general director of Britain's Royal United Services Institute (RUSI): "EU-NATO relationship will be crucial, if the West wants to survive as a coherent entity" (John Andreas Olsen, 2020).

It should be taken into consideration, that especially in the strategic documents from 2000 onwards, NATO's role has been increasingly emphasized as strengthening its military component in finding an appropriate response and resolving modern: crises, conflicts and wars. . On the other hand, in this period, the strategic goal of the EU was to create an international network in order to successfully and efficiently deal and prevent modern nonmilitary crises that are outside Article 5 of the North Atlantic Treaty agreement.

All this mention above led us to logical and comprehensive approach for unification of NATO and EU forces in a common umbrella as a future EU body to deal with any kind of non-military crises, including health crises or pandemics such as the current health pandemic caused by COVID-19. This very logical reason for unification of NATO and EU forces in one body that will be part of the EU, means that this body needs to have own coordinated and continuous effective cooperation with the UN, World Health Organization and other international organizations and institutions which actively work in dealing with health crises (Jim Garamone, 2020)

Preventive fields of cooperation between NATO and EU are divided in seven areas that cover: hybrid threats, operational cooperation, cyber security, defense capacities and capabilities, military industry, joint military and civil defense exercises and of course the most important scientific research work (NAT0 Press Release, 2016: 177-178).

Later, these seven areas of cooperation between NATO and EU were intensified in 74 concrete actions. The first benefits of intensified cooperation between NATO and EU from 2016 could be seen in the Joint Declaration from July 2018, where it is clearly emphasized that the mutual cooperation progresses is visible with concrete results and realization of foreseen strategic goals (Drent, Kruijver, Zandee, 2019 :6-8).In this direction, no less important is the logistical dimension of: production, transport and supply of necessary medical equipment for prevention from COVID-19 to countries that need urgent assistance from them. Regarding the part of logistics activities related to the production, transport and supply of necessary 
medical equipment, we would emphasize that in the future all this should be the basic competence of NATO and EU civil protection mechanism.

\section{Conclusion}

In the context of NATO and EU dealing with the global pandemic caused by COVID-19 as well as possible future pandemics, they should take a more serious step towards consolidating military-civilian capacities and capabilities. They need to have medium- and long-term rapid response plans from event of unpredictable non-military threats, similar to COVID-19. Lack of true information or fake news is another problem for preventing COVID-19 and future similar challenges (, , 2020: 155-157).

It is necessary to give even more priority and support to military-civilian authorities in order to take comprehensive measures to deal effectively and efficiently with global pandemics. Here, we would especially like to emphasize the role of the NATO EARDCC (EuroAtlantic Disaster Response Coordination (enter), which is an effective disaster response mechanism in the Euro-Atlantic area. This NATO body is constantly active at the operational level and its core network of cooperation consists of all NATO partner and member countries.

The main task of NATO EARDCC is to prevent non-military threats which are outside of operations provided with Article 5 of North Atlantic Treaty agreement.

In this regard, the organizational structure of the NATO Response Force (NRF) will be used frequently for non-military crisis management operations. The NATO Response Force also needs to be networked and integrated into the public health partnership framework.

EADRCC represent a major step forward in collective efforts of NATO to provide assistance to populations struck by major disasters. Moreover, it attests the willingness of NATO to engage in practical cooperation in an area of vital concern to all nations and to provide an operational capability and capacities (NAT0, 2001: 54-55). Here we will especially emphasize the need for even better cooperation of NATO Response Force and NATO EARDCC with European Union. The experience gained from dealing with global pandemics throughout history is another serious indicator in which direction is needed to transform the organizational structure of NATO and EU in order for their cooperation in dealing and preventing consequences of some future global pandemics to be even more effective (Marrone, Credi, 2020: 7-8).

As real leadership steps, we will emphasize the bilateral relations which Republic of Serbia has established with: NATO, EU, USA, Russia and China. They resulted with efficient supply of more than necessary medical equipment for rapid prevention of consequences from pandemic caused by COVID-19. We will also point out that Republic of Serbia selflessly extended a hand and donated part of the medical equipment for dealing with COVID-19 for some of South East Europe region states. From the countries which received assistance from Republic of Serbia during the first wave of COVID-19 during the second half of 2020, was also Republic of North Macedonia (Gjurovski, Dronzija, Djukanović, 2021:61-64).

At the same time in EU there is a certain dysfunction of international intellectual elite for the current global turbulences that are visible and observed from other countries. EU funds are insufficient to prevent all unpredictable challenges both regionally and globally. European economic crisis that follows the COVID-19 pandemic and the relations between the United States and China are a present and a future famine that will affect a large part of humanity (Vankovska, 2020, 83-84). 
COVID-19 pandemic showed that globally the international organizations: UN, NATO, EU should comprehensively strengthen and intensify cooperation and coordination in order to effectively deal with the current pandemic and some future threats and challenges to humanity (Tchakarova, Satanakis, 2020:3-5). On the other hand, if intensified cooperation between USA and China doesn't occur soon, not only in the part of dealing with health crises like the current one with COVID-19, but even more in the part of corporate economic cooperation, then according to most of the scientific and expert public the chances of a military conflict between the two superpowers by 2030 is very possible, which could have lasting consequences for the existence of humanity (European Parliament, 2020:51).

\section{References:}

1. Andreas Olsen John. Future of NATO: Adapting to new realities," (London: Royal United Services Institute, April 4, 2020), https://rusi.org/publication/whitehall-papers/futurenato-adapting-new-realities

2. Beach Brain, Clay Karen, Saavedra H. Martin. The 1918 influenza pandemic and its lessons for Covid-19. National bureau of economic research, Massachusetts Avenue Cambridge, August 2020.

3. Becker Sophia, Hellmonds Soren, Molling Christian, Schultz Torben. Covid-19 and European defense voice from capitals, DGAP, 2021.

4. BiEPAG. The Western Balkans in Times of the Global Pandemic, EU Policy Brief, April 2020.

5. Drent Margriet, Kruijver Kimberley, Zandee Dick. Military Mobility andEUNATOConundrum, Clingendael Report, July 2019.

6. European Parliament. How the COVID-19 crisis has affected security and defense related aspects of EU, European union, 2021.

7. European Parliament. The Geo-political implications of COVID-19 pandemic. European union, 2020.

8. Garamone Jim. NATO Takes Steps to Combat Coronavirus," DOD News, April 6, 2020, Explore/News/Article/ Article/2139462/nato-takes-steps-to-combat-coronavirus/ (accessed August 20, 2021).

9. Giovanna De Maio. NATO's response to Covid-19: Lessons for Resilience and readiness. Brookings Foreign policy, 2020.

10. Gjurovski Marjan, Dronzija Tatjana, Djukanović Dragan. Security and Covid-19- The Political and Security System, Regional Security Forecasts and New State Actors Before and During the Pandemic.Konrad-Adenauer Stiftung and UKLO, Skopje, 2021.

11. Global initiative against transnational organized crime. Covid-19 and crime - A response develops at the UN, Un Policy Brief, june 2020.

12. Iftimie A. Ion. The implications of COVID-19 for NATO's counter-bioterrorism in COVID-19: 
NATO in the Age of Pandemics ed. Thierry Tardy, (Rome: NATO Defence College, May 1 , 2020), https://www.jstor. org/stable/resrep25148.12.

13. Latici Tania. NATO's response in the fight against coronavirus, European Parliamentary research service, june 2020.

14. Marrone Alessandro and Ottavia Credi. COVID-19: Which Effects on Defence Policies in Europe?, Istituto Affari Internazionali, 2020. https://www.iai.it/sites/ default/ files/ iai2009.pdf

15. NATO defense and security committee. The role of NATO's armed forces in the covid-19 pandemic, draft special report by Attila Mesterhazy. chairperson of the dsctc,.2020.

16. NATO. NATO's Response to COVID-19 Pandemic, Factsheet, February 2021.

17. NATO. NATO's role in disaster assistance, NATO, 2001.

18. SACEUR remarks on COVID-19 Task Force. SHAPE, available at: https://shape.nato.int/ saceur/saceur-remarks-on-covid19-taskforce

19. Snyder Terry. Navy support to civilian authorities during the 1918 influenza pandemichistory's lessons and recommendations for future work. Military Medicine, No.174, November 2009.

20. Spinney L. Pale rider: The Spanish Flu of 1918 and how it changed the World, New York, Public Affairs, Hachette Book Group, 2017.

21. Statement on the implementation of the Joint Declaration signed by the President of the European Council, the President of the European Commission, and the Secretary General of the North Atlantic Treaty Organization, NATO Press Release (2016).

22. Taubenberger J, Morens D. "1918 influenza: the mother of all pandemics- Emerging Infectious Diseases, Vol.12, No.1, 2000.

23. Tchakarova Velina, Satanakis Maria Sofia. EU-NATO relations: Enhanced cooperation: Admit increased uncertainty, Austrian institute for Europe, 2020.

24. Thierry Tardy. Covid-19: NATO in the age of Pandemics, NATO defense college in Rome, September 2020.

25. Vankovska Biljana. Dealing with COVID-19 in the European periphery: between securitization and "gaslighting" Journal of Global Faultlines, 2020, Vol. 7, No. 1.

26. Wever P.C, Bergen L. Death from 1918 pandemic influenza during the First World War: A perspectivefrom personal and anecdotal evidence. Influenza and Other Respiratory Viruses, Vol.8, №.5, 2014.

27. Zartsdahl Horne Peter. Civil-military synergies in EU crisis response and peacebuilding: A framework for analysis, Global affairs, 2018.

28. European commission. Economic policy coordination in 2021: overcoming COVID-19, supporting the recovery and modernising our economy, Brussels, 2.6.2021 COM 500 


\section{Internet links:}

1. Euro-Atlantic Disaster Response Coordination Centre (EADRCC), accessed on 15.07.21 https://www.nato.int/cps/en/natohq/topics 117757.htm

2. Gobierno De España - Minister for Defence underlines (2020) "Need for coordination between NATO and EU" to tackle COVID-19. Acessed on 20.09.21 https://www.lamoncloa. gob.es/lang/ en/gobierno/news/Paginas/2020/20200415covid19-nato-eu.aspx)

3. Lye Harry. (2020). NATO could support members more through COVID-19: Army Technology poll. Accessed on 05.09 .21 https://www.armytechnology.com/features/natocould-support-members-morethrough-covid-19-army-technology-poll

4. NATO and Civil Emergency Response. (2018). Marking 20 Years since the Creation of the Euro-Atlantic Disaster Response Coordination Centre. Acessed on 10.09 .21 https://www. nato.int/cps/en/natohq/news_155087.htm

5. NATO Centre for Maritime Research and Experimentation (CMRE), accessed on 07.07.21, https://www.cmre.nato.int/rockstories-blog-display/528-cmre-covid19-model

6. NATO Science and Technology Organization (STO), accessed on $16.07 .21 \mathrm{https://www.}$ nato.int/cps/en/natohq/topics_88745.htm

7. NATO Support and Procurement Agency (NSPA), accessed on 10.07.21 https://www.nspa. nato.int/en/index.htm

8. NATO. (2020). EADRCC Clearing house mechanism, accessed on 14.09.21 https://www. nato.int/nato static fl2014/assets/pdf/2020/4/pdf/200401-EADRCC-Requestingassistance-in 3.pdf)

9. NATO. (2020). NATO clearing house mechanism accessed on $15.08 .21 \mathrm{https://www.}$ nato.int/nato static fl2014/assets/pdf/2020/4/pdf/200401-EADRCC-Requestingassistance-in 3.pdf

10. Wemer David. (2020). NATO Allies have stepped up to help each other during Coronavirus. Accessed on 01.08.21 https://atlanticcouncil.org/blogs/new-atlanticist/nato-allieshave-stepped-up-to-help-each-other-during-coronavirus-emergency

11. Worldometers.info/coronavirus/ last update 07.09.2021. 